\title{
UNEQUILIBRATED ULTRAMAFIC XENOLITHS FROM UDACHNAYA KIMBERLITE PIPE, WESTERN YAKUTIA.
}

\author{
Evgenii E. Laz'ko and Victor P. Serenko.
}

Institute of Ore Deposits Geology, Petrography, Mineralogy \& Geochemistry, USSR Academy of Sciences,

Moscow, USSR.

Uncommon garnet-bearing ultramafic rocks from kimberlites which contain unequilibrated mineral associations are of great importance for interpretation of mantle petrogenesis and dynamics. Several types of such xenoliths have been found in Udachnaya kimberlite pipe (Sobolev et al., 1984; Laz'ko, 1988 ). The most interesting samples among them as regards to mantle processes study are: xenoliths with zoned garnets; peridotites with homogeneous minerals (within a single crystal) which composition vary appreciably from grain to grain; "polymict peridotite type" ultramafic rocks containing fragments of unrelated mineral parageneses.

PERIDOTITES WITH ZONED GARNETS. These samples are the most common variety of uneqilibrated ultramafic xenoliths in Yakutian kimberlites (Serenko et al., 1982; Laz'ko, Serenko, 1983). All of them are typical sheared peridotites with mosaic or fluidal-mosaic textures in which recrystallized olivine, abundant porphyroclasts of pyroxenes and rounded garnet grains are present. A zoning in the latter can be seen sometimes in a hand specimen. Purple transparent core of such garnets are surrounded by orange highly cracked rim.

The proper example of peridotite with zoned garnets is large $(10 * 6 * 6$ $\mathrm{cm})$ xenolith TUV-43. The diameter of garnet grains in it reaches up to 6-8 $\mathrm{mm}$. A pronounced concentric symmetrical zoning of the mineral have been detected by a microprobe. Garnet have strong core-to-rim decreases in $\mathrm{Cr}_{2} \mathrm{O}_{3}$ and increases in $\mathrm{TiO}_{2}$ contents. I.ess prominent rise has been found for $\mathrm{Al}_{2} \mathrm{O}_{3}$ and $\mathrm{FeO}$ concentrations in the same direction. CaO content slightly decreases and oxidation rate of $\mathrm{Fe}$ grows from core to $\mathrm{rim}$ :

\begin{tabular}{lcccccccc} 
Oxides & Outer & \multicolumn{2}{c}{ Intermediate } & \multicolumn{2}{c}{ zones } & \multicolumn{2}{c}{ Core } & Outer \\
& zone1 & 2 & 3 & 4 & 5 & 6 & 7 & zone2 \\
$\mathrm{TiO}_{2}$ & 1.22 & 1.16 & 1.13 & 0.93 & 0.34 & 0.02 & 0.08 & 1.15 \\
$\mathrm{Al}_{2} \mathrm{O}_{3}$ & 18.8 & 18.5 & 18.9 & 18.0 & 17.9 & 18.1 & 17.8 & 19.2 \\
$\mathrm{Cr}_{2} \mathrm{O}_{3}$ & 3.87 & 4.30 & 1.95 & 6.07 & 6.67 & 6.96 & 7.54 & 3.78 \\
$\mathrm{FeO}$ & 9.07 & 8.80 & 8.34 & 8.64 & 7.82 & 7.59 & 7.67 & 8.27 \\
$\mathrm{CaO}$ & 5.10 & 5.07 & 5.12 & 5.41 & 5.62 & 5.95 & 6.11 & 5.07 \\
$\mathrm{Fe}^{3+} / \mathrm{Fe}_{\text {tot }}, \%$ & 19.6 & 20.3 & 15.5 & 10.3 & 10.0 & 10.6 & 7.1 & 17.6
\end{tabular}

The garnets composition smoothly vary in outer parts of grains only at a distance $0.2-0.7 \mathrm{~mm}$ from the edges of crystals. Cores of garnets in TUV-43 peridotite $(2-6 \mathrm{~mm}$ thick) are homogeneous and have almost identical composition in all examined grains. On the contrary, external parts of the latter have rather different composition even in adjacent grains. In particular the difference in $\mathrm{Cr}_{2} \mathrm{O}_{3}$ contents exceeds $1.5 \mathrm{wt} . \%$.

Other minerals of TUV-43 peridotite are homogeneous and chemically equilibrated with outer Ti-rich rim of garnet. Olivine contains 89.1-89.5 of Fo-molecule, orthopyroxene $\mathrm{En}_{90.4-90.7}$ has low $\mathrm{Al}_{2} \mathrm{O}_{3}$ content $-0.55-0.65$ wt.\%. Subcalcic clinopyroxene composition ( $\mathrm{mg}=0.902, \mathrm{Ca} / \mathrm{Ca}+\mathrm{Mg}=38.0-38.5 \%$ ) is indicative of a high-temperature origin of the sample $\left(>1200^{\circ} \mathrm{C}\right)$. Bulk rock is strongly exhausted by $\mathrm{Al}_{2} \mathrm{O}_{3}(0.96 \mathrm{wt} . \%)$ and $\mathrm{CaO}(0.95$ wt.\%) but degpite such depletion it nevertheless contains rare phlogopite plates with "equilibrium" primary-type appearance. 
PERIDOTITE WITH HOMOGENEOUS GARNETS OF DIFFERENT COMPOSITION. Yenoliths of this variety are rather rare in Udachnaya pipe (Pokhilenko; Sobolev, 1978; Laz'ko et al., 1983). A small $(3 * 2 * 2 \mathrm{~cm})$ nodule TUV-177 from our collection belongs to sheared texture type rocks and contains garnets of different color, fron bright purple to dark orange one. A composition of individual garnet porphrroclasts is almost homogeneous except very weak increase of $\mathrm{TiO}_{2}$ and FeO contents accompanied by decrease in $\mathrm{Cr}_{2} \mathrm{O}_{3}$ in the outmost parts of few grains. However different porphyroclasts composition varies distinctly from grain to grain $\left(\mathrm{Cr}_{2} \mathrm{O}_{3} 2.26-4.11 ; \mathrm{TiO}_{2} 0.39-1.17\right.$; FeO 7.41-8.96). A clear negative correlation exists between $\mathrm{Cr}_{2} \mathrm{O}_{3}$ and $\mathrm{TiO}_{2}, \mathrm{Cr}_{2} \mathrm{O}_{3}$ and $\mathrm{FeO}$ contents. Besides garnets peridotite contains abundant porphyroclasts of orthopyroxene (Eng0; $\mathrm{Al}_{2} \mathrm{O}_{3}=0.48$ wt.\%) and clinopyroxene $\quad(\mathrm{mg}=0.90$. $\mathrm{Ca} / \mathrm{Ca}+\mathrm{Mg}=41 \%)$, which are cemented by partly serpentinized fine-grained olivine Fog9. The composition of separate grains of $a i l$ constituent minerals except garnet in TUV-177 xenolith is identical. The texture of the rock is fluidal-mosaic with stroig foliation. These feature are indicative of a particularly intensive deformation of the rock in high-temperature mantle conditions $\left(\mathrm{T}=1136^{\circ} \mathrm{C}\right)$.

"POLYMICT PERIDOTITE" TYPE ULTRAMAFIC ROCKS. Xenoliths with fragments of unrelated unequilibrated mineral associations partly resembling "polymict" mantle samples from Bultfontein and De Beers kimberlites (Lawless et al., 1979 ) are particularly rare in Yakutian diatremes. Unic xenolith of this type (TUV-29) consists of two quite different (in terms of chemical composition) mineral associations which probably have not been formed at the same time.

The main association is a intensively deformed garnet olivinite with olivine porphyroclasts Fo84-86 and few smal] scattered grains of violet garnet. The latter belongs to high- $\mathrm{Cr}_{2} \mathrm{O}_{3}$ and $10 \mathrm{w}-\mathrm{CaO}$ "diamondiferous peridotites" (Pokhilenko, Sobolev, 1986) variety (tahle 1). However Fe/Fe+Mg

Table 1. Composition of minerals in TUY-29 nodule.

\begin{tabular}{|c|c|c|c|c|c|c|c|c|c|c|}
\hline & 1 & 2 & 3 & 4 & 5 & 6 & 7 & 8 & 9 & 10 \\
\hline & 01 & 01 & Gnt & Gnt & $\mathrm{Cpx}$ & $\mathrm{Cps}$ & Gint & $\operatorname{cin} t$ & $11 \mathrm{~m}$ & $\mathrm{I} \mathrm{lm}$ \\
\hline $\mathrm{iO}_{2}$ & 39.7 & 38.9 & 40.0 & 40.4 & 55.3 & 55.1 & 41.9 & 41.4 & - & - \\
\hline $\mathrm{TiO}_{2}$ & .00 & 0.00 & 0.06 & 0.11 & 0.23 & 0.23 & 0.70 & 0.56 & 47.7 & 48.7 \\
\hline $\mathrm{Al}_{2} \mathrm{O}_{3}$ & 0.00 & 0.00 & 14.0 & 13.8 & 1.73 & 2.46 & 20.9 & 20.8 & 1.22 & 0.68 \\
\hline $\mathrm{Cr}_{2} \mathrm{O}_{3}$ & 0.02 & 0.00 & 10.9 & 11.5 & 0.16 & 0.24 & 0.74 & 0.66 & 0.99 & 0.94 \\
\hline $\mathrm{FeO}$ & 13.1 & 15.1 & 10.7 & 12.0 & 4.35 & 3.69 & 12.7 & 13.1 & 38.8 & 36.3 \\
\hline no & 0.13 & 0.15 & 0.49 & 0.58 & 0.07 & 0.07 & 0.27 & 0.46 & 0.17 & 0.25 \\
\hline 10 & 0.31 & 0.18 & 0.00 & 0.00 & 0.03 & 0.01 & 0.05 & 0.07 & 0.15 & 0.14 \\
\hline go & 46.2 & 44.7 & 18.6 & 17.2 & 16.6 & 16.4 & 17.0 & 17.8 & 10.9 & 11.1 \\
\hline $\mathrm{a} 0$ & 0.05 & 0.07 & 3.82 & 4.35 & 0.1 & 19.3 & 5.53 & 4.96 & - & \\
\hline $\mathrm{a}_{2} \mathrm{O}$ & - & - & 0.00 & 0.00 & 1.38 & 1.84 & 0.00 & 0.00 & - & - \\
\hline$\overline{t a}$ & 9.51 & 99.10 & 98.57 & 99.94 & 99.95 & 99.34 & 99.79 & 99.81 & 99.93 & 8. \\
\hline & 86.3 & 84.1 & 75.6 & 71.9 & 87.2 & 88.8 & 70.5 & 70.8 & 40.6 & 2.1 \\
\hline
\end{tabular}

1,2 - coarse grained olivine; 3,4 - violet garnet; 5 - clinopyroxene, large crystal; 6 - clinopyroxene included into orange garret; 7 - large orange garnet; 8 - orange garnet included into clinoprovene; 9 - ilmenite, inclusion in garnet; 10 - veined ilmenite in olivine matrix.

of garnets from TUV-29 is almost twice higher than in actual diamond-bearing dunites and harzburgites from Udachnaya pipe (Pokhilenko, Sobolev, 1986).

At the peripheral part of the xenolith large rounded crystals of orange low $\mathrm{Cr}_{2} \mathrm{O}_{3}$ garnet up to $2 \mathrm{~cm}$ in diameter and elongated pale-green FeO-rich clinopyroxene (up to $3 \mathrm{~cm}$ ) are present. These phases form the main volume of a second mineral association. They strongly resemble the megacrysts of a lowCr association widely spread in kimberlites both by appearance and in terms 
of composition Garnets and clinopyroxenes of "megacrystic" association contain numerous drop-like ilmenite inclusions up to $1 \mathrm{~cm}$ in diameter, intergrowths of phlogopite with $1-2$ wt.\% $\mathrm{TiO}_{2}$ and tiny $\mathrm{Cu}-\mathrm{Ni}-\mathrm{Fe}$ sulfide globules. Additionally, narrow veins of ilmenite cross the olivine matrix of the main rock. A distribution of minerals in the xenolith and the lack of their compositional equilibrium suggest that "megacrystic" association was formed later than primary garnet olivinite had crystallized and was plastically inserted into the latter rock synchronously with deformation. At the same time in a process of recrystallization the mg-numbers of constituent minerals in olivinite have been partly decreased.

DISCUSSION. Unequilibrated high-temperature ultramafic xenoliths from kimberlites are peculiar "snapshots" of subcratonic mantle rocks and conditions just before magma eruption and therefore such nodules are invaluable tool to decipher various mantle processes. Samples like peridotite TUV-177 are suggested to be related to large-scale intensive mixing of hot plastic mantle rocks. In the case under consideration mixing apparently was extremely "dry" process since the indications of melt or fluid presence in the evolved peridotite are negligible. On the contrary, an origin of garnets' zoning similar to one examined in the xenolith TUV-43 are among the best examples of contamination during deformation of depleted peridotites by fluid or highly fluidized melt. The metasomatic agent completely escaped out of the rock after zoning had been formed. The signs of synchronous mixing, melting, deformation and chemical changes of deforming rocks in mantle are even more convincing from TUV-29 xenolith study. We conclude that unequilibrated ultramafic rocks are indicative of an intimate connection of magmatism, fluid mass transfer, and large scale deformation at the regions of kimberlite melt generation in mantle. The total process including kimberlite parental magma origin may be explained by a diapiric ascent of large volume of hot plastic partially melted asthenosphere and it's interaction with relatively cold subcratonic lithosphere.

\section{REFERENCES}

LARLESS P.l., GURNEY J.J., DARSON J.B. 1979. Polynict peridotites fro the Buitfontein and De Beers Kines, Ribberley, south Africa. In Boyd P.R. and Meyer H.O.A. eds, The Nantle Sample, p.p. 145-155. Aner. Geophys Union, Mash., D.C.

LA2'RO E.E. 1988. Ultranafic rantle xenoliths in kimberlites. In Laz'ko E.E. and Sharkov E.V. eds, Ultranafic rocks, p.p. 346379, Nauka Publ. Coupany, Moscow (in Russian).

LAZ'RO B.E and SERENGO V.P. 1983. Peridotites with qoned garnets fron Yakutian kimberlites: evidence of high-teaperature deepseated netasonatis» and vantle diapirisn? Trans. USSR Acad. Sci., ser. Beol., No, 12, p.p. 41-53 (in Russian).

LAZ'RO E.E., SERENRO V.P., MURAPITSZAYA G.N. 1983. Sheared peridotite with a garnet of variable copposition fron Udachnaya kinberlite pipe (Yakutia). Rept. USSE Acad. Sci,, v. 268, No. 6, p.p. 1458-1462 (in Russian).

PORHILEMRO N.P. and SOBOLEV N.V. 1978. Garnets of different couposition in sheared lherzolite fron Udachnaya kinberlite pipe, Yakutia. RI INA Meet. Novosibirsk, Abstr. v. 2, p. 9 (in Russian).

PORHILENGO N.P. and SOBOLEV N.V. 1986. Renoliths of diamondiferous peridotites fron Udachnaya kiberlite pipe, Yakutia. Geol. Soc. Austral. Abstr., No. 16, p.p. 309-311.

SRRENKO V.P., NIRISHOV R.N., LAZ'RO E.E. 1982. Zoned garnets in porphiroblastic lherzolites frou Mir kinberlite pipe. Rept. USSR Acad. Sci., v. 267, No. 2, p.p. 438-441 (in Bussian).

SOBOLEY N.V., PORHLLEAEO N.P., RODIONOV A.S. 1984. Inhonogeneities of the deep seated inclusions in kiuberlites as an indication of the processes of dynanic evolution in upper antle sabstance. 27th IGC sess. Moscow, Abstr. v. 5, p.p. 399-400. 